Chirurgia (2019) 114: 739-746

No. 6, November - December

Copyright@ Celsius

http://dx.doi.org/10.21614/chirurgia.114.6.739

\title{
Intragastric Fluid Filled Balloon for Weight Reduction - A Single Bariatric Center Study
}

\author{
Gerald Filip, Simona Filip, Bogdan Dumbrava
}

General Surgery Department, Center of Excellence in Bariatric Surgery, Ponderas Academic Hospital, Bucharest, Romania

Corresponding author:

Gerald Filip, MD

General Surgery Department

Center of Excellence in Bariatric

Surgery, Ponderas Academic

Hospital, Bucharest, Romania

E-mail: geraldfilip71@yahoo.com

\section{Abbreviations:}

$\mathrm{BMI}$ - body mass index

$\mathrm{Cl}$ - confidence interval

IGB - intragastric balloon

$I Q R$ - interquartile range

$\mathrm{OR}$ - operating room

SD - standard deviation

TWL - total weight loss
Received: 19.11.2019

Accepted: 20.12.2019

\section{Rezumat}

Balonul intragastric cu lichid pentru scădere ponderală - experiența unui centru de bariatrie

Introducere: Obezitatea este o problemă de sănătate pandemică şi este însoțită de scăderea semnificativă a speranței de viață, datorită asocierii cu afecțiuni severe: complicații cardiovasculare, pulmonare, dermatologice, gastrointestinale, urinare, reproductive şi psihiatrice. Balonul montat endoscopic intragastric şi umplut cu lichid reprezintă o variantă minim invazivă folosită pentru scăderea în greutate. Multiple studii au demonstrat superioritatea acestei metode endoscopice în reducerea morbidității şi mortalitătii asociate cu obezitatea. Datele pe termen lung sunt limitate dar nu se anticipează menținerea scăderii ponderale mai mult de 1 an în afara unui program nutritional dedicat. Studiul prezentat evaluează siguranța şi eficacitatea balonului intragastric montat endoscopic la pacienții care s-au adresat unui centru de excelența în tratamentul obezității.

Material şi Metodă: Studiul prezentat a fost efectuat retrospectiv, evaluând experiența unui centru de chirurgie bariatrică, în perioada octombrie 2017 - octombrie 2019. Studiul a cuprins pacienți la care s-a efectuat implantarea endoscopică a balonului gastric umplut cu ser fiziologic urmată de extragerea sa după 6 luni.

Rezultate: Au fost analizaț 44 de pacienți cu vârsta medie de 36 ani. Lotul a cuprins 34 de femei (77\%) şi 10 barbați (23\%). BMI mediu a fost de $32,65 \mathrm{~kg} / \mathrm{m}^{2}$, iar BMI mediu la extracția balonului (după 6 luni) a fost de $28.83 \mathrm{~kg} / \mathrm{m}^{2}$. Perioada de internare a fost de 24 de ore pentru 40 de pacienți (91\%) şi de 48 de ore pentru 4 pacienți (9\%). Au fost înregistrate complicații minore la 8 pacienți (18\%) dar nu au fost pacienți la care a fost nevoie de extragere balon.TWL a fost de $11,76 \%$. 
Concluzie: Datele obținute prin acest studiu demonstrează beneficiul terapeutic al baloanelor cu lichid montate intragastric. La sfârşitul celor 6 luni, greutatea pacienților, BMI şi greutatea în exces a fost semnificativ mai scăzute comparativ cu măsuratorile efectuate la începutul tratamentului. Este nevoie de studii suplimentare pentru o mai bună evaluare pe termen lung (după extragerea balonului) a acestei metode terapeutice.

Cuvinte cheie: tratament minim invaziv obezitate, balon intragastric, endoscopie superioară

\begin{abstract}
Introduction: Obesity is a pandemic health problem which significantly reduces life expectancy because of its strong association with severe cardiologic, respiratory, dermatological, gastrointestinal, genito-urinary and psychiatric complications. Intragastric fluid filled balloon (IGB) is a minimally invasive option for weight reduction. Several studies have demonstrated its superiority to lifestyle changes in reducing the morbidity and mortality associated with obesity. Long-term data is very limited, while the balloons are not anticipated to maintain weight beyond 1 year unless an efficient nutritional program is maintained.

Aim: This study evaluated the safety and efficacy of intragastric fluid filled balloon in the weight reduction process for patients referred for weight cutback in a center of excellence in bariatric surgery.

Methods: This is a retrospective, single institution study which included all the consecutive patients opting for gastric balloon therapy at Ponderas Academic Hospital, Bucharest between October 2017 and October 2019. Two surgeons certified in endoscopy performed the procedures of implantation and extraction.

Results: Forty-four patients were included in this study, with a mean age of 36 years. There were $34(77 \%)$ females and $10(23 \%)$ males. The mean index BMI was $32.56 \mathrm{~kg} / \mathrm{m}^{2}$ and the mean BMI after 6 months (post extraction of the balloon) was $28.83 \mathrm{~kg} / \mathrm{m}^{2}$. Length of stay was 24 hours for 40 (91\%) of patients and 48 hours for $4(9 \%)$ patients. Minor complications were registered in 8 (18\%) cases and these were not followed by balloon extraction. Overall total weight loss (TWL) mean was $11.76 \%$.

Conclusions: Our data demonstrated a clear benefit of intragastric fluid-filled balloon on weight loss, after six month placement of the balloon. At the end of treatment, body weight, excess body weight and BMI were significantly lowered as compared with initial measurements. Successful weight loss was defined as $\geq 10 \%$ weight loss after 6 months with intragastric balloon in situ. Further research is needed in order to better define the long-term results after balloon extraction.
\end{abstract}

Key words: minimally invasive bariatric treatment, intragastric balloon, upper GI endoscopy

\section{Introduction}

Obesity is a significant risk factor for and contributor to increased morbidity and mortality, notably from cardiovascular disease and diabetes, but also from cancer and other chronic disease such as osteoarthritis, liver and chronic kidney pathology, sleep apnea, and depression (1). The prevalence of obesity has increased steadily over the past 5 decades and has reached alarming levels in the European Union, including in Romania, where there is an estimated prevalence of $20-25 \%$ (2). This may have a significant impact on quality-adjusted life years. Obesity is also strongly associated with an increased risk of all-cause mortality (3).

According to BMI, general population is classified in five categories: underweight (BMI 
$<18.5 \mathrm{~kg} / \mathrm{m}^{2}$ ), normal weight (BMI 18.5-24.9 $\mathrm{kg} / \mathrm{m}^{2}$ ), class I obesity - overweight (BMI 25.0$29.9 \mathrm{~kg} / \mathrm{m}^{2}$ ), class II obesity - obesity (BMI 30.0-39.9 kg/m²), class III obesity - extreme obesity $\left(\mathrm{BMI}>40 \mathrm{~kg} / \mathrm{m}^{2}\right)$.

The currently available endoscopic options for the management of obesity can be divided in three categories (4):

- space-occupying devices within the stomach known as intragastric balloons (filled with saline or air)

- gastric remodeling devices. These devices utilize endoscopic suturing in order to reduce the volume of the stomach by approximately $70 \%$. The greater curvature of the stomach is folded onto itself to create a tube within the stomach.

- devices that work in the small intestine. These devices are placed under endoscopic and radiographic guidance and bypasses approximately $65 \mathrm{~cm}$ of the small intestine, from the duodenum to the proximal jejunum. They target to prevent food from mixing with bile and pancreatic secretion until it reaches the small intestine.

The major advantage of intragastric balloons (IGBs) is that they preserve the anatomy of the stomach. The fluid-filled balloons work by delaying the rate of gastric emptying; thus, the patients will consume smaller meals and feel satiety longer.

Compared with endoscopic plication and bariatric surgical procedures, intragastric balloons are temporary - the stimulus that resulted in weight loss is removable (5). The balloons can be combined with lifestyle interventions and medications to create an effective weigh loss strategy.

After their introduction in 1982, numerous studies showed that IGBs are an effective and low-cost method to achieve temporary weight loss in morbidly obese individuals, leading to significant decrease in morbidity and mortality rates. Intragastric balloons are used as bridge to surgery for patients who need medical treatment for associated disease (cardiovascular, respiratory, diabetes) before surgical procedure. Weight reducing effects of intragastric balloons significantly reduce the mortality, morbidity and risks associated with invasive surgery. Intragastric balloons are the most widely available endoscopic bariatric therapy for class I and II obesity in the United States (4).

Endoscopic implantation and subsequent removal of intragastric balloon is a safe method and the risk of incidents, accidents and major adverse events is low. Nausea, vomiting and abdominal cramps are common side effects as the stomach must tolerate a foreign body. These symptoms are not anymore present in $90 \%$ of the patients taking medication, within the first two weeks after balloon implantation. The air-filled balloon seems to be associated with less nausea and abdominal cramps than the fluid-filled balloons (4). However, it also appears to be less effective than fluid-filled balloons in terms of weight loss. Serious adverse events are rare and include gastric perforation, perforation of the balloon with consecutive balloon migration and small bowel obstruction, gastric ulcer, worsening of gastroesophageal acid reflux.

Not all the candidates can tolerate the potential side effects of intragastric balloon. According to the literature, more than 5\% of the patients will not endure the adverse effects (persistent nausea, vomiting, abdominal pain) and will require balloon removal within the first 14 days after implantation $(5,6)$.

Long term data is limited, but gastric balloons are not anticipated to maintain weight loss beyond 12 months. However, the American Society for Metabolic and Bariatric Surgery, the American Gastroenterological Association and the American Society for Gastrointestinal Endoscopy (ASGE) recommend using the gastric balloons as a weight loss strategy and to combine them with active lifestyle and behavioral interventions as well as obesity medications in order to extend the persistence of weight loss for the long term after balloon removal $(4,7)$.

\section{Materials and Methods}

All consecutive patients, opting for gastric balloon therapy at Ponderas Academic Hospital, Bucharest between October 2017 and October 
2019 were included in this retrospective study. There were selected for evaluation only those patients who received silicon based intragastric fluid-filled balloon with a maximal volume of $700 \mathrm{ml}$ and which was removed six months after, as per manufacturer's recommendations.

Exclusion criteria referred to the patients with air-filled balloons, long term Spatz balloons and those who needed removal of fluid filled gastric balloon within the first month after implantation.

All the subjects underwent a standard evaluation before procedure. This included clinical examination, blood tests, upper GI endoscopy, barium swallow test, abdominal ultrasound, EKG, psychological evaluation, nutritional assessment and preoperative anesthesia assessment. Patients with large hiatal hernias (more than $3 \mathrm{~cm}$ ), reflux esophagitis, gastroduodenal ulcer, history of gastric surgery, psychiatric disorders and contraindications for general anesthesia were not considered for the IGB procedure.

Written informed consent was taken from all the patients, risks and benefits were explained.Additionally, patients were asked to be included in a behavioral intervention program, tailored to their standard lifestyle. This included diet modifications, physical activity and follow-up after balloon insertion at 1-3-6 months.

\section{Intragastric Balloon Implantation}

All procedures were done in the operating room (OR), under general anesthesia. The patients were connected to vital monitoring devices and placed in supine position with a right arm peripheral intravenous line.

After endotracheal intubation, the procedure begins with upper endoscopy; the gastroscope was advanced under direct visualization through esophagus and stomach to the duodenum. The endoscope was withdrawn after complete examination for the presence of grossly anatomical contraindications.

The balloon was inserted thereafter into the oral cavity and pushed into the stomach with the attached introduction catheter. A repeat endoscopy was performed afterwards. Under direct visualization, the balloon was adjusted for proper intragastric placement followed by retraction of the guidewire. The next step was the balloon inflation (Fig. 2). Normal saline solution was utilized in the process, up to a maximum of 650-700 mls. An additional $10 \mathrm{mls}$ of methylene blue was injected and mixed with the saline. On achieving the desired inflation, the balloon catheter was gently pulled out, leaving the balloon in stomach. The scope was gently retracted with careful examination of the balloon (for position, integrity, leaks). The procedure ended with close examination of the anatomy and the integrity of the mucosa during removal of the endoscope. A subsequent barium swallow test (Fig. 3) would confirm the correct placement and probity of the balloon.

Median time for implantation procedure was 28 minutes (range 22-40).

The patients were subsequently trans-

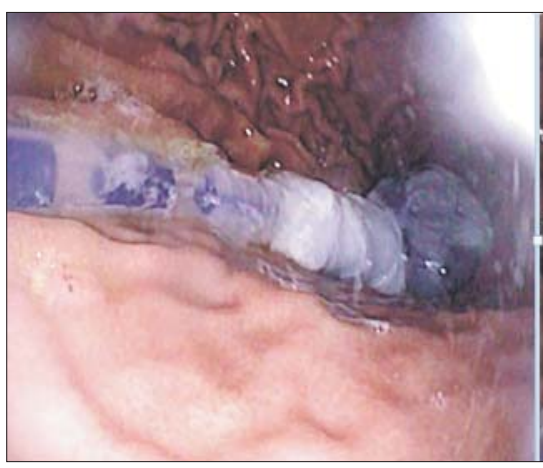

Figure 1. Balloon placement

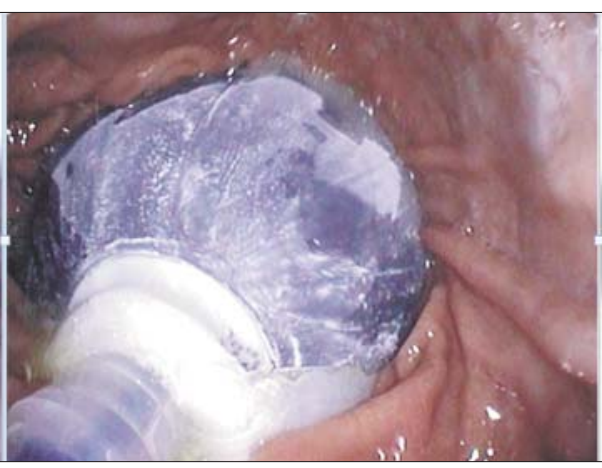

Figure 2. Balloon inflation

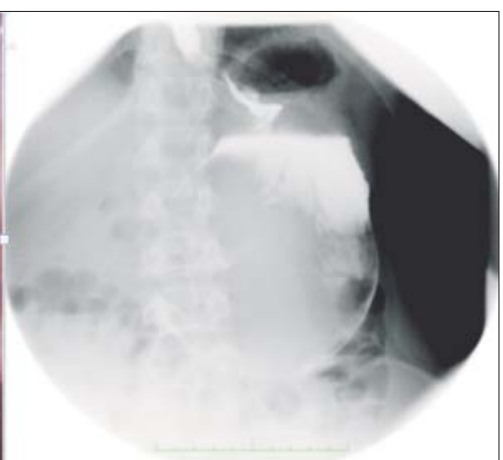

Figure 3. Barium swallow test 
ferred to the recovery area for observation. The discharge was done after 24 hours and after making sure that the minimal adverse effects (nausea, vomiting, pain) were controllable by oral medication.

\section{Intragastric Balloon Removal}

The extraction of the balloon was done after 6 months, according with the manufacturer's recommendation.

Similar protocol was followed for the removal of the balloon under general anesthesia. After endoscopic inspection (Fig. 4) and aspiration of gastric content, an aspiration needle was inserted into the balloon (Fig. 5). This was followed by complete withdrawal of the fluid from the balloon (Fig. 6). The balloon, now fully deflated, was then explanted by using an endoscopic grasping forceps. A repeat endoscopic examination of stomach, cardia and esophagus was then performed. The patients were transferred to recovery and discharged the same day.

\section{Statistical Analysis}

Statistical analysis was done in $\mathrm{R} \otimes$ Version 3.5.3 Copyright (C) 2019 The R Foundation for Statistical Computing, R Core Team (2019). R: A language and environment for statistical computing. $\mathrm{R}$ Foundation for Statistical Computing, Vienna, Austria. URL https:// www.R-project.org

For categorical variables we calculated absolute frequency and relative frequency, and for continuous variable we calculated mean, standard deviation, median, inter quartile range, minimum value, maximum value and range of the distributions.

To compare the values of BMI before surgery and at the moment of extraction we used a paired $\mathrm{T}$ test (the normality of data was checked with Smirnov-Kolmogorov test).

The level of significance was considered 0.05 .

\section{Results}

The initial study included 50 patients. One patient was excluded due to adverse reactions and consecutive balloon extraction after 6 days. Five patients did not turn up for balloon extraction. The same protocol was followed in all 44 analyzed patients, consisting in evaluation before and after the procedure, with follow-up at 1,3 and 6 months when the balloon was extracted. The main documented parameters were weight, BMI and total weight loss (TWL\%). The age range of both males and females was between 19 to 65 years, with median value 39.50 and IQR equal to 16.50 .

All the endoscopic procedures have been done under general anesthesia to maximize the security of the procedure. The median time for implantation was 28 minutes (range 22-40) and median time for removal procedure was 36 minutes (range 25 - 45). There were no incidents or accidents recorded during the procedures of implantation or removal.

The endoscopic procedures were performed

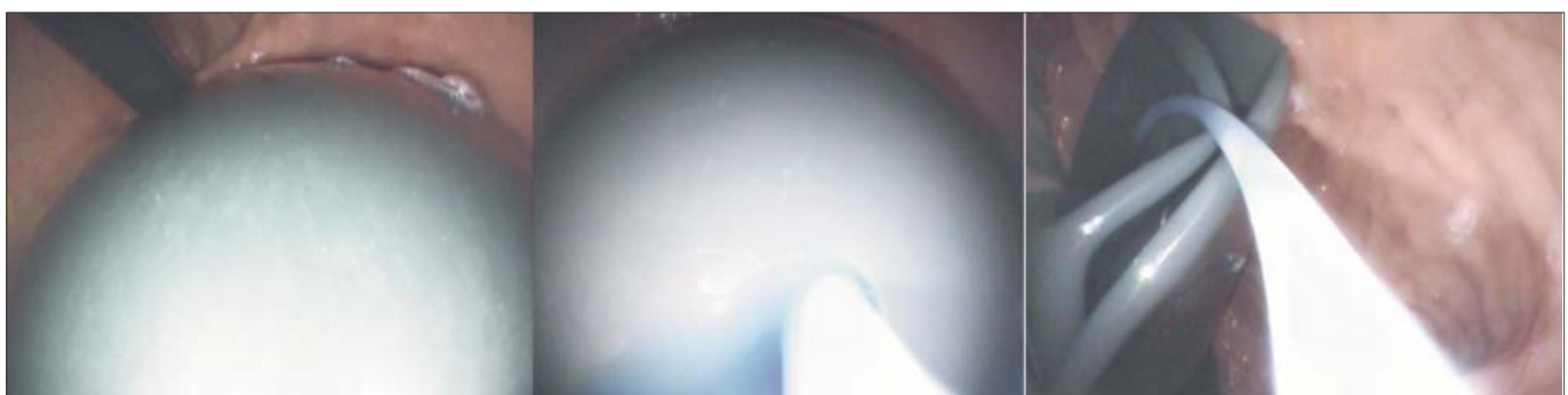

Figure 4. Balloon check-up J maneuver Figure 5. Balloon exsufflation
Figure 6. Completed balloon exsufflation 
Table 1.

\begin{tabular}{lc}
\hline Variable & Patients Group \\
\hline Age & \\
Mean \pm S.D. & $36.25 \pm 10.85$ \\
Median (IQR) & $39.50(16.50)$ \\
Min - Max (Range) & $16.00-52.00(36.00)$ \\
\hline Gender & $10(23 \%)$ \\
Male - N (\%) & $34(77 \%)$ \\
Female - N (\%) & $32.56 \pm 8.12$ \\
BMI & $29.75(7.95)$ \\
Initial Mean \pm S.D & $23.90-61.00(36.90)$ \\
Median (IQR) & \\
Min - Max (Range) & $28.83 \pm 8.35$ \\
BMII & $26.75(8.02)$ \\
Extraction Mean \pm S.D & $18.60-59.50(30.90)$ \\
Median & \\
Min - Max (Range) & $40(91 \%)$ \\
Length of Stay & $4(9 \%)$ \\
One Day - N (\%) & \\
Two Days - N (\%) & $8(18 \%)$ \\
Complications & $36(82 \%)$ \\
Yes - N (\%) & \\
No - N (\%) & $36.13 \pm 5.56$ \\
\hline Operating Time & \\
Mean \pm S.D & \\
\hline
\end{tabular}

as day-cases. Most of the adverse events were minor, such as nausea, vomiting and abdominal discomfort. These usually happened in the first 24 hours post balloon implantation. Eight $(18 \%)$ patients were unable to tolerate oral fluids and $4(9 \%)$ patients needed admission for another 24 hours. There were no balloon perforations, balloon migrations, gastric ulcers or GI bleeds in this case series.

For BMI comparison - Index BMI vs BMI at extraction we use a paired t-test (Table 2).

There was a statistically significant difference at $p<0.001$, the mean of differences was 3.73 , median of the differences was 3.70 , minim value of the differences was -1.40 (at least one patient gained weight), maximum value of the differences was 10.00 .

The Graph 1 shows BMI comparison before surgery (B) vs BMI at balloon extraction (E).

As the histogram of differences in BMI

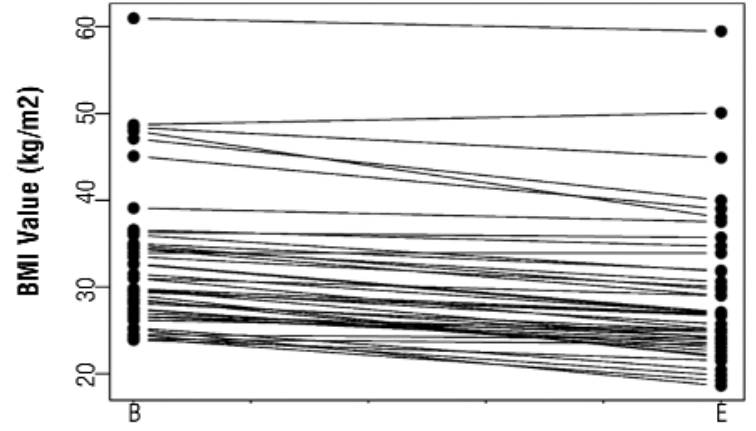

Graph 1. BMI comparison initial vs extraction

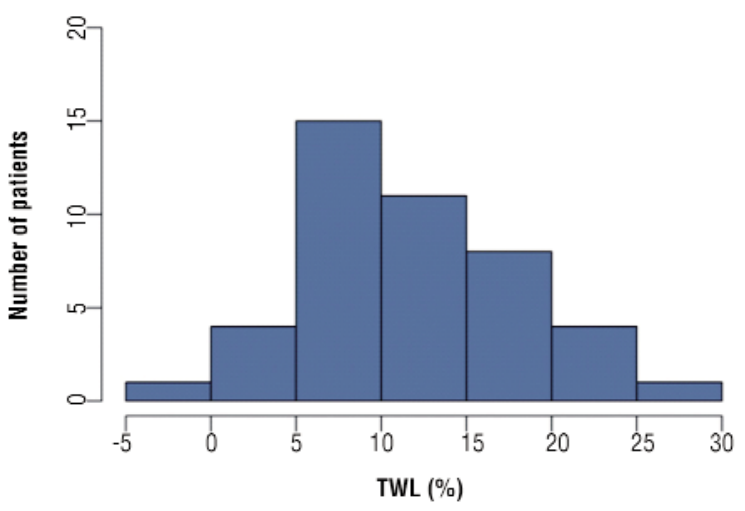

Graph 2. Histogram of patient's TWL

shows and the result of Kolmogorov-Smirnov test for normality $(p=0.9143)$, the distribution of differences between index BMI and BMI at 6 months was almost gaussian. This suggests that weight loss depends on factors specific to each individual. There are differences in metabolism, alimentary patterns, gender (Graph 2).

TWL (total weight loss) mean was $11.76 \pm$ $6.54 \%$, median was $10.35 \%$, Inter Quartile Range (IQR) was $10.55 \%$, min value was $2.89 \%$ and maximum value was $25.97 \%$.

The TWL distribution was roughly normal as well, (histogram and $\mathrm{p}$ value from Kolmogorov-Smirnov test $=0.0597$ ). This

Table 2.

\begin{tabular}{lccc}
\hline Index BMI Mean & BMI Extraction Mean & P value & Differences' Mean [CI 95\%] \\
\hline 32.56 & 28.83 & $<0.001$ & $3.73[0.23$ to 7.21$]$ \\
\hline
\end{tabular}


further highlight the variability of characteristics of each patient.

Anthropometric evaluation was performed 6 -months after the IGB extraction in 34 patients and the results are as follows:

- $16(47 \%)$ patients maintained the weight and BMI after balloon extraction;

- 9 (23\%) underwent gastric sleeve to complete the treatment;

- $7(20 \%)$ patients have returned to the index BMI from the beginning of the treatment;

- $3(8 \%)$ patients exceeded the index BMI and weight.

\section{Discussions}

Intragastric balloon implantation is essentially a restrictive, non-surgical procedure. It was shown to increase satiety and decrease residual volume via stretch receptors (8), as well as to decrease gastric capacity. The procedure is less invasive, it is reversible and repeatable. This makes it attractive for patients. On the flip side, the treatment itself is only temporary, in a direct relation to the duration of having the IGB.. The mean duration of IGB implantation in our series was 6 months.

There was a high incidence of nausea and vomiting in the first 48 hours of balloon placement, keeping in line with other studies $(9,10)$. These symptoms were countered with the prophylactic prescription of antiemetic drugs. Thus, in the first days only 4 patients $(9 \%)$ were in need for prolonged hospital stay with further 24-hours of fluid and medication support. Proton pump inhibitors are compulsory to use in view of protecting the gastric mucosa against gastroesophageal reflux and the balloon itself from the destructive action of hydrochloric acid.

The analysis of our results shows similar outcomes with published data in the literature in terms of weight loss, BMI and TWL during the preservation of the intragastric balloon. A similar paper was published by Portuguese authors (11). In their study, there were 34 patients with the same demographic and balloon preservation parameters. The Portuguese patients experienced significant reductions in weight correlated to baseline values (range 93.8 to $81.9 \mathrm{~kg}, \mathrm{p}<0.001$ ), BMI (range 35.8 to $31.8 \mathrm{~kg} / \mathrm{m}^{2}, \mathrm{p}<0.001$ ), similar to the cases in our study. We measured a mean index BMI of $32.56 \mathrm{~kg} / \mathrm{m}^{2}$ and a mean BMI after 6 months (post extraction of the balloon) of $28.83 \mathrm{~kg} / \mathrm{m}^{2}$. In our study, the mean BMI reduction was 3.73 which is statistically significant. The distribution of the differences between BMI and TWL is gaussian which is in line with patients' individual factors.

Kotzampassi et al. (12) obtained better results in a study that encompassed a larger pool of 195 patients. They demonstrated that $83 \%$ of patients have had a weight loss of more than $20 \%$ at the time of balloon removal and almost a quarter at the 60-month follow-up out of 195 obese patients. However, we have found that after temporary IGB implantation in overweight or obese individuals, a weight loss greater than $10 \%$ of baseline weight was achieved in $86.5 \%$ of participants. Similar Joana Ribeiro da Silva et al.(8) reported the same good results with a smaller number of subjects, of 35 .

It has been demonstrated that the procedure is safe with a low rate of complications associated with. Moreover, the intervention is reproductible, easy to perform with minimal facilities and skill set. Placement and removal of intragastric balloons are facile procedures to master; thus, endoscopists with formal endoscopy skills could safely perform them. Beside this aspect, the endoscopists who want to introduce intragastric balloons to their practice should be aware that a mandatory program to support their patients and administer appropriate follow-up, lifestyle interventions, and behavioral interventions is always needed.

The strength of our study is that it has been performed in single institution with a great experience in bariatric surgery. In this manner, we offered the patients not only the endoscopic procedure, but the full array of weight loss program tailored to each individual and a strict follow-up protocol. The data in our 
study shows that $47.05 \%$ of patients were able to maintain their weight and BMI at 6 months post extraction and $23.55 \%$ needed further bariatric procedures to improve the results in the treatment of obesity.

One important limit to our research so far is the finite pool of patients that went through the entire process of having the procedure and then medium-term follow-up. Only 34 out of the initial 50 patients were able to be monitored.

The main inquiry is whether the patients' diet and lifestyle can be properly paired with this brief endoscopic procedure to cause significant weight loss. The literature results on long-term effectiveness of intragastric balloons are in contradiction. Some studies conclude that patients may regain partially or even the whole initial weight after the balloon has been removed. In other series, the results are encouraging(13). The consistency of weight loss during IGB therapy and then having it sustained after removal was comparable. Research from Imaz et al. (11), Dogan et al. (7), Fuller et al. (14), Genco et al. (15), Herve et al. (16), Ohta et al. (17), and Sallet et al.(18) report encouraging results that after extraction of the balloon.

\section{Conclusions}

The use of intragastric fluid-filled balloon results in significant weight loss in selected obese patients. Almost half of the patients (47\%) include in a Bariatric Center follow-up program maintained the weight and BMI after balloon extraction.

The major priority for further research in this field is identifying responders and nonresponders to this intervention. Although these procedures are safer than surgery, not everybody will respond; tools such as physiologic measurements (i.e. rate of gastric emptying) may help identify who will respond to the balloon at baseline.

\section{Conflict of Interest}

The authors declare no conflicts of interests.

\section{References}

1. Enache G. Prevalence of Overweight and Obesity in a Roma Population from Southern Romania - Calarasi County. Acta Endocrinol [Internet]. 2018;14(1):122-30.

2. Mundi I. Romania Obesity - adult prevalence rate.

3. Pi-Sunyer X. The medical risks of obesity. Postgrad Med. 2009; 121(6):21-33.

4. Abu Dayyeh BK, Kumar N, Edmundowicz SA, Jonnalagadda S, Larsen M, Sullivan S, et al. ASGE Bariatric Endoscopy Task Force systematic review and meta-analysis assessing the ASGE PIVI thresholds for adopting endoscopic bariatric therapies. Gastrointest Endosc. 2015;82(3):425-38.

5. Hill C, Khashab MA, Kalloo AN, Kumbhari V. Endoluminal weight loss and metabolic therapies: current and future techniques. Ann N Y Acad Sci. 2018;1411(1):36-52.

6. Mohamed Ibrahim. Short-term results of intragastric balloon for management of Egyptian obese patients. Egypt J Surg. 2019; 38(4):802-6.

7. Dogan UB, Gumurdulu Y, Akin MS, Yalaki S. Five Percent Weight Lost in the First Month of Intragastric Balloon Treatment May Be a Predictor for Long-Term Weight Maintenance. Obes Surg. 2013;23(7):892-6.

8. Ribeiro da Silva J, Proença L, Rodrigues A, Pinho R, Ponte A, Rodrigues J, et al. Intragastric Balloon for Obesity Treatment: Safety, Tolerance, and Efficacy. GE - Port J Gastroenterol. 2018;25(5):236-42

9. Jamal MH, Almutairi R, Elabd R, AlSabah SK, Alqattan H, Altaweel T. The Safety and Efficacy of Procedureless Gastric Balloon: a Study Examining the Effect of Elipse Intragastric Balloon Safety, Short and Medium Term Effects on Weight Loss with 1-Year Follow-Up Post-removal. Obes Surg. 2019;29(4):1236-41.

10. Bazerbachi F, Vargas EJ, Abu Dayyeh BK. Endoscopic Bariatric Therapy. Am J Gastroenterol. 2019;114(9):1421-31.

11. Imaz I, Martínez-Cervell C, García-Álvarez EE, Sendra-Gutiérrez JM, González-Enríquez J. Safety and Effectiveness of the Intragastric Balloon for Obesity. A Meta-Analysis. Obes Surg. 2008;18(7): 841-6.

12. Kotzampassi K, Grosomanidis V, Papakostas P, Penna S, Eleftheriadis E. 500 Intragastric Balloons: What Happens 5 Years Thereafter? Obes Surg. 2012:22(6):896-903.

13. Saleh Almeghaiseeb E, Farooq Ashraf M, Abdullah Alamro R, Omar Almasoud A, Ali Alrobayan A. Efficacy of intragastric balloon on weight reduction: Saudi perspective. World J Clin Cases. 2017; 5(4):140-147.

14. Fuller NR, Pearson S, Lau NS, Wlodarczyk J, Halstead MB, Tee H-P, et al. An intragastric balloon in the treatment of obese individuals with metabolic syndrome: A randomized controlled study. Obesity. 2013; 21(8):1561-70

15. Genco A, Cipriano M, Materia A, Bacci V, Maselli R, Musmeci L, et al. Laparoscopic sleeve gastrectomy versus intragastric balloon: a case-control study. Surg Endosc. 2009;23(8):1849-53.

16. Herve J, Wahlen CH, Schaeken A, Dallemagne B, Dewandre JM, Markiewicz S, et al. What Becomes of Patients One Year after the Intragastric Balloon has been Removed? Obes Surg. 2005; 15(6):864-70.

17. Ohta M, Kitano S, Kai S, Shiromizu A, Eguchi H, Endo Y, et al. Initial Japanese Experience with Intragastric Balloon Placement. Obes Surg. 2009;19(6):791-5.

18. Sallet JA, Marchesini JB, Paiva DS, Komoto K, Pizani CE, Ribeiro MLB, et al. Brazilian Multicenter Study of the Intragastric Balloon. Obes Surg. 2004;14(7):991-8. 